\title{
Depletion and enrichment processes in lithospheric mantle beneath the Baltic Shield (Kola peninsula and Arkangelsk) - evidence from laser ICP-MS analyses of mantle minerals
}

\author{
Beard, A.D. ${ }^{1}$, Mason, P.R.D. 2,3 and Downes, H. ${ }^{1}$
}

1. Department of Geology, Birkbeck College, Malet St, London WC1E 7HX, U.K.

2. Institute of Earth Sciences, University of Utrecht, P.O. Box 80021, 3508 TA, Utrecht, Netherlands.

3. formerly at: NERC ICP-MS Facility, ICCET, Imperial College, Silwood Park, Ascot, Berks, SL5 7TE, U.K.

Using the method described by Mason et al (this volume), high precision laser ablation ICP-MS data for incompatible trace elements have been obtained from single grains of clinopyroxene, hornblende and apatite from ultramafic lithospheric xenoliths found in Devonian kimberlites and related rocks of the Kola and Arkangelsk regions, NW Russia.

\section{Arkangelsk spinel and garnet peridotites}

The range of REE patterns in clinopyroxenes from Arkangelsk mantle xenoliths is very wide. HREE concentrations are often below chondritic values, indicating that an extremely strong depletion has occurred in this region of the cratonic lithospheric mantle. This may be due to extensive partial melting, perhaps related to production of $\mathrm{Mg}$-rich magmas such as komatiites during Archaean/Proterozoic times. The clinopyroxenes show variable LREE-enrichment; their $\mathrm{La}_{n} / \mathrm{Yb}_{\mathrm{n}}$ ratios vary over several orders of magnitude (0.6-770), with the most strongly LREE-enriched grains coming from garnet peridotite xenoliths. Some clinopyroxenes from LREE-enriched spinel peridotites show a slight depletion in La and $\mathrm{Ce}$ relative to $\mathrm{Nd}$. One grain from a spinel peridotite shows a strong variation in $\mathrm{La} / \mathrm{Y} \mathrm{b}_{\mathrm{n}}$ from a LREE-depleted core to a LREE-enriched rim, perhaps indicating an advancing diffusion front of LREE. This variation could be due either to interaction with the host magma during eruption or to metasomatism while still in the lithospheric mantle.

Mantle-normalised incompatible trace element patterns for the clinopyroxenes are also very variable. Many of the strongly LREE-enriched clinopyroxenes are also enriched in $\mathrm{Sr}, \mathrm{Th}$ and $\mathrm{U}$, but show large negative anomalies in $\mathrm{Nb}$ and moderate negative anomalies in $\mathrm{Zr}$, features common to many LREE-enriched clinopyroxenes from mantle xenoliths (Mason et al., this volume). The negative $\mathrm{Zr}$ anomaly probably results from extensive partial melting. Clinopyroxenes that show low La and Ce contents also have low Rb, Ta, U and $\mathrm{Nb}$ contents; this feature may indicate that xenoliths that were LREE-enriched have 
undergone some degree of subsequent melt removal. Amphibole of probable metasomatic origin is moderately LREE-enriched $\left(\mathrm{La}_{n} / \mathrm{Yb}_{n}=10.5\right)$ and has very high concentrations of $\mathrm{Rb}$ (350ppm), Nb (8ppm), Zr (78ppm) and Sr (640ppm).

\section{Kola spinel peridotites}

Clinopyroxene and amphibole were analysed from small (1-2cm diameter) sheared and granular spinel peridotite xenoliths in a monticellite kimberlite from Kola (Beard et al., in press). The sheared xenolith contains metasomatic phlogopite, whereas the granular ones contain amphibole and apatite. A region consisting of $\mathrm{Cr}$-diopside, chromite, $\mathrm{Cr}$-spinel, perovskite, monticellite, amphibole and apatite is present in one granular xenolith and appears to be a frozen pocket of precursor melt related to the monticellite kimberlite.

The clinopyroxene data reveal a lithospheric mantle with moderate to low levels of HREE. Clinopyroxenes from the sheared xenolith have $\mathrm{Yb}$ concentrations at chondritic levels, significantly lower than HREE abundances generally found in clinopyroxenes from spinel peridotites in Phanerozoic regions, confirming the extreme depletion of the mantle of the Baltic Shield. Overprinted on the depletion is a moderate but variable enrichment in LREE, related to the texture of the xenolith. Clinopyroxene from the sheared xenolith has $\mathrm{La}_{\mathrm{n}} / \mathrm{Yb}_{\mathrm{n}}=4-7$; those from granular xenoliths have greater LREE-enrichment with $\mathrm{La}_{n} / \mathrm{Yb}_{\mathrm{n}}=11-19$. Clinopyroxene from the "frozen kimberlite pocket" has a REE pattern intermediate between these two. Using Kds from Zack et al. (1996), the calculated REE pattern of a melt in equilibrium with these Cr-diopsides is identical to that of the host montcellite kimberlite. REE patterns in amphiboles also vary with texture of the xenoliths. Those from sheared xenoliths have convex upward REE patterns and low total REE contents; those from granular xenoliths are concave upward and have an order of magnitude greater total REE abundances. Both have positive $\mathrm{Nb}$ anomalies and relatively low $\mathrm{U}$ and Th contents.

In their mantle-normalised trace element patterns, clinopyroxenes from the granular xenoliths show strong depletions in $\mathrm{Zr}$ and $\mathrm{Nb}$ but are enriched in $\mathrm{Th}$ and $\mathrm{U}$. Those from the sheared xenolith do not have negative $\mathrm{Zr}$ and $\mathrm{Nb}$ anomalies. Their mantle-normalised diagrams instead shows a smoothly humped pattern, with depletion in both the least incompatible elements ( $\mathrm{Y}$ and HREE) and in the most incompatible elements ( $\mathrm{Rb}, \mathrm{Th}, \mathrm{U}$, $\mathrm{Nb}$ ). Clinopyroxenes from the frozen melt pocket also lack the $\mathrm{Zr}$ and $\mathrm{Nb}$ anomalies, but are enriched in $\mathrm{Rb}, \mathrm{Th}, \mathrm{U}$ and $\mathrm{Nb}$. The trace element data suggest that this depleted lithospheric mantle was metasomatised by magmas related to the widespread Devonian ultramafic magmatism in the region. 


\section{Kola hornblendites and glimmerites}

These xenoliths occur in lamprophyres and carbonatites (Beard et al., 1996) and range from layered pyroxenite-hornblendite rocks to pure hornblendites and glimmerites. Apatite can be abundant in the hornblendites (up to 20\%). Amphiboles from these metasomatic rocks are variably LREE-enriched $\left(\mathrm{La}_{n} / \mathrm{Yb}_{n}=5-30\right)$. They all show strong positive $\mathrm{Nb}$ anomalies in mantle-normalised patterns and many also show strong positive $\mathrm{Zr}$ anomalies, which correlate with the presence of apatite in the buk rock. Mantle-normalised abundances of Th and $\mathrm{U}$ tend to be lower than those of the LREE, whereas $\mathrm{Rb}$ values are usually much higher than the LREE. These characteristics relate to the crystal chemistry of amphibole. In direct contrast to clinopyroxene, amphibole has a strong affinity for $\mathrm{Rb}$ and $\mathrm{Nb}$, but rejects $\mathrm{U}$ and $\mathrm{Th}$ from its structure. Apatites from these xenoliths are extremely LREE-enriched $\left(\mathrm{La}_{\mathrm{n}} / \mathrm{Yb}_{\mathrm{n}}=15-112\right)$ and have very large negative $\mathrm{Nb}$ and $\mathrm{Zr}$ anomalies, forming mirror-images of the amphibole patterns. Clinopyroxene from the hornblendites have variable REE patterns ( $\left.\mathrm{Lan}_{n} / \mathrm{Yb} \mathrm{b}_{\mathrm{n}}=5-22\right)$ and negative $\mathrm{Nb}$ and $\mathrm{Sr}$ anomalies; however, the clinopyroxene with the highest LREE enrichment $\left(\mathrm{Lan}_{n} / \mathrm{Yb}_{n}=108\right)$ comes from a glimmerite xenolith. It also has the highest $\mathrm{Nb}(9 \mathrm{ppm})$ and $\mathrm{Zr}(170 \mathrm{ppm})$ contents. These data indicate that metasomatism was probably related to a wide variety of undersaturated melts and can produce extreme trace element enrichment in the lithosphere.

\section{References}

Beard, A. D., Downes, H., Vetrin, V., Kempton, P. D. and Maluski, H., 1996, Petrogenesis of Devonian lamprophyre and carbonatite minor intrusions, Kandalaksha Gulf (Kola Peninsula, Russia). Lithos 39, 93-119.

Beard A.D, Downes, H., Hegner, E., Sablukov, S. M., Vetrin, V.R. and Balogh, K., in press, Mineralogy and geochemistry of Devonian ultramafic minor intrusions of the southern Kola Peninsula, Russia: implications for the petrogenesis of kimberlites and melilitites. Contrib. Mineral. Petrol.

Mason, P. R. D., Downes, H., Jarvis, K. and Vannucci, R. (this volume), An investigation of incompatible trace elements in Massif Central mantle xenoliths by laser ablation ICP-MS: implications for mantle processes.

Zack, T., Foley, S. F. and Jenner, G.A., 1996, A consistent partition coefficient set of 21 trace elements for clinopyroxene, amphibole and garnet through laser ablation microprobe analysis of garnet pyroxenites from Kakanui, New Zealand. J. Conf. Abstracts 1, p 691. 